\title{
The clinical impact of CYP2C19*2 and *3 polymorphism on Clopidogrel and cost analysis
}

\author{
Al Meman A*, Khalaf H, Rasool Seemab \\ From 2nd International Genomic Medical Conference (IGMC 2013) \\ Jeddah, Kingdom of Saudi Arabia. 24-27 November 2013
}

\section{Background}

Inter individual variability to Clopidogrel response is well recognized as a strapping barrier in front of clinicians. It has been mentioned that the pharmacogenetic variations may explain 30-50 percent in this variability $[1,2]$. Several recent landmark studies have proven the importance of 2C19 genotyping in treatment using clopidogrel [1-3]. Therefore we sought to investigate the variability in PFT response to CYP2C19 polymorphism and compare it with the clinical presentation. Furthermore, cost analysis is considered.

\section{Materials and methods}

One hundred and seventy Saudi patients who were stable on $75 \mathrm{mg}$ clopidogrel at least for one month for various cardiac indications were enrolled in Prince Sultan Cardiac Center, Buraidah. DNA was extracted by MagNAPure [LC,Roche, Germany].CYP2C19 Genotyping for "1, "2 and "3 was conducted by real-time PCR [Roche Molecular Biochemicals, Mannheim, Germany]. PFT was carried out by (Verify Now P2Y12) for all the patients. The clinical events were documented retrospectively for all patients.

\section{Results}

One hundred seventeen patients presented with the wild variant $1 / 1,19$ patients with $1 / 2$, and 34 patients with $2 / 2$. We couldn't detect allele 3 . There is a significant association between different genotyping and the percentage of inhibition $(P=0.0002) .1 / 1$ patients tend to be moderate to - extensive metabolizers, whereas the majority of the rest are slow metabolizers. One hundred twenty three patients presented with no symptoms. Interestingly, no association was found between the adequacy of the PFT and the clinical symptoms $(\mathrm{P}=0.60)$ and PPIs did not

\footnotetext{
* Correspondence: ahmadalmeman@gmail.com

Intervention group at Prince Sultan Cardiac Center, Qassim \& Genetic laboratory at Qassim University, Kingdom of Saudi Arabia
}

affect the overall response. Furthermore, Aspirin dose didn't impact on the clinical symptoms $(P=0.080)$. The cost of doing the PFT is $250 \mathrm{SR} /$ patient and $200 \mathrm{SR} /$ patient (real-time PCR) for kits and materials excluding equipment and labors.

\section{Conclusions}

Although the platelet function testing varied significantly with polymorphism, the clinical symptoms were not associated. The running cost is affordable if clinical association was found to be significant.

Published: 2 April 2014

\section{References}

1. Mega JL, Close SL, Wiviott SD, et al: Cytochrome P-450 polymorphisms and response to clopidogrel. N Engl J Med 2009, 360:354-362.

2. Simon T, Verstuyft C, Mary-Krause M, et al: Genetic Determinants of Response to Clopidogrel and Cardiovascular Events. N Eng J Med 2009, 360:363-75.

3. Collet JP, Hulot JS, Pena A, et al: Cytochrome P450 2C19 polymorphism in young patients treated with clopidogrel after myocardial infarction: a cohort study. The Lancet 2009, 373(9660):309-317.

doi:10.1186/1471-2164-15-S2-P19

Cite this article as: Meman A et al.: The clinical impact of CYP2C19*2 and ${ }^{*} 3$ polymorphism on Clopidogrel and cost analysis. BMC Genomics 2014 15(Suppl 2):P19.

Submit your next manuscript to BioMed Central and take full advantage of:

- Convenient online submission

- Thorough peer review

- No space constraints or color figure charges

- Immediate publication on acceptance

- Inclusion in PubMed, CAS, Scopus and Google Scholar

- Research which is freely available for redistribution
() Biomed Central

(c) 2014 Al Meman et al; licensee BioMed Central Ltd. This is an Open Access article distributed under the terms of the Creative Commons Attribution License (http://creativecommons.org/licenses/by/2.0), which permits unrestricted use, distribution, and reproduction in any medium, provided the original work is properly cited. 